\title{
PELAKSANAAN PERATURAN WALIKOTA PEKALONGAN NOMOR 35 TAHUN 2010 TENTANG SISTEM DAN PROSEDUR PEMUNGUTAN BEA PEROLEHAN HAK ATAS TANAH DAN BANGUNAN SERTA PERMASALAHANNYA DI KOTA PEKALONGAN
}

\author{
Ikayanti, $^{*}$ Jawade Hafidz ${ }^{* *}$ \\ * Mahasiswa Program Magister (S2) Kenotariatan Fakultas Hukum UNISSULA, Semarang, e-mail: \\ alifanaura@gmail.com \\ ** Dosen Fakultas Hukum UNISSULA, Semarang
}

\begin{abstract}
One of the taxes levied by the district/city government is the right to land and buildings (BPHTB). Implementation in Pekalongan City based on Pekalongan Perwal No. 35 of 2010. As done in the implementation of Pekalongan Perwal No. 35 of 2010 in processed is a mandatory dishonesty, so that checks the location of objects subject to BPHTB and for taxpayers can not be given and adjusted with compulsory conditions tax.

Keywords : Mayor Regulation and Customs Acquisition of Land and Building Rights
\end{abstract}

\section{PENDAHULUAN}

Sumber pendapatan negara atau keuangan negara terbesar di Indonesia berasal dari penerimaan pajak. Di dalam Ensiklopedi Indonesia disebutkan bahwa pajak ialah suatu pembayaran yang dilakukan kepada pemerintah untuk membiayai pengeluaranpengeluaran yang dilakukan dalam hal penyelenggaraan jasa-jasa, untuk kepentingan umum. ${ }^{1}$

Pajak memang merupakan kewajiban warga negara dalam sebuah negara (termasuk negara Islam), tetapi negara berkewajiban pula untuk memenuhi 2 (dua) kondisi atau syarat sebagai berikut : ${ }^{2}$

a. Penerimaan hasil-hasil pajak harus dipandang sebagai amanah dan dibelanjakan secara jujur dan efisien untuk merealisasikan tujuan-tujuan pajak;

b. Pemerintah harus mendistribusikan beban pajak secara merata di antara mereka yang wajib membayarnya.

Pajak daerah dan retribusi daerah merupakan salah satu sumber pendapatan daerah yang penting guna membiayai pelaksanaan peme-rintahan daerah. Salah satu pajak daerah kabupaten/kota yang

\footnotetext{
${ }^{1}$ M. Ali Hasan, Masail Fiqhiyah, Zakat, Pajak, Asuransi dan Lembaga Keuangan, Edisi Pertama, Cetakan Kedua, Raja Grafindo Persada, Jakarta, 1997, hlm. 29.

2 Gusfahmi, Pajak Menurut Syariah, Edisi Revisi, Cetakan Kedua, Rajawali Pers, Jakarta, 2011, hlm. 161.
}

menjadi sumber pendapatan daerah sebagaimana disebutkan di dalam Undang-Undang Nomor 28 Tahun 2009 adalah Bea Perolehan Hak atas Tanah dan Bangunan (BPHTB).

Mengenai BPHTB diatur tersendiri di dalam Undang-Undang Nomor 20 Tahun 2000. Mengenai prosedur pemungutan BPHTB ini, masing-masing diatur di dalam peraturan daerah, sebagaimana halnya di Kota Pekalongan diatur di dalam Peraturan Daerah Kota Pekalongan Nomor 8 Tahun 2010 tentang Bea Perolehan Hak Atas Tanah dan Bangunan, yang ditindaklanjuti dengan Peraturan Walikota Nomor 35 Tahun 2010 tentang Sistem dan Prosedur Pemungutan Bea Perolehan Hak Atas Tanah dan Bangunan.

Peristiwa hukum seperti jual-beli, hibah, lelang dan sebagainya sering terjadi di dalam masyarakat. Akan tetapi, para pihak (subjek pajak) ada yang tidak membayar BPHTB tersebut. Padahal BPHTB merupakan salah satu pemasukan bagi daerah, yang nantinya akan dipergunakan untuk pembangunan daerah.

Pemungutan pajak oleh aparat perpajakan membawa beberapa implikasi, salah satunya adalah pembayaran pajak secara riil akan mengurangi uang wajib pajak (WP) yang dapat dibelanjakan (disposable income). Oleh karena itu, wajib pajak akan selalu mencari cara untuk mengurangi beban pem-bayaran pajak, bahkan kalau perlu menghindar 
dari kewajiban ini. ${ }^{3}$

Adanya otonomi daerah yang memberikan hak kepada daerah untuk mengembangkan potensi yang dimiliki daerah, perlu mendapatkan dukungan dari masyarakat daerah, salah satunya dengan membayar BPHTB yang merupakan pajak daerah. Pemerintah daerah pun juga harus berupaya agar warga daerah mau membayar pajak dengan mempergunakan cara-cara dan prosedur yang baik, sehingga warga daerah tidak merasa terpaksa dalam memenuhi kewajibannya untuk membayar pajak, karena pada dasarnya pajak tersebut nantinya dipergunakan untuk memenuhi segala kebutuhan masyarakat daerah.

Dari uraian latar belakang di atas, penulis merumuskan per-masalahan sebagai berikut: Bagaimanakah pelaksanaan Perwal Pekalongan Nomor 35 Tahun 2010 di Kota Pekalongan?; Apa sajakah kendala yang dihadapi di dalam pelaksanaan Perwal Pekalongan Nomor 35 Tahun 2010 di Kota Pekalongan?; Bagaimanakah upaya di dalam mengatasi kendala-kendala di dalam pelaksanaan Perwal Walikota Pekalongan Nomor 35 Tahun 2010 di Kota Pekalongan?

\section{PEMBAHASAN}

1. Pelaksanaan Perwal Pekalongan Nomor 35 Tahun 2010 di Kota Pekalongan;

Salah satu pajak daerah yang dipungut oleh pemerintah kabupaten/ kota adalah Bea Perolehan Hak Atas Tanah dan Bangunan (BPHTB), yang juga merupakan pemasukan bagi Pendapatan Asli Daerah di tiap-tiap daerah, termasuk di Kota Pekalongan. Pemungutan BPHTB dilakukan melalui sistem dan prosedur, yang telah diatur di dalam Peraturan Walikota Pekalongan Nomor 35 Tahun 2010 tentang Sistem dan Prosedur Pemungutan Bea Perolehan Hak Atas Tanah dan Bangunan. ${ }^{4}$

Sistem dan prosedur pemungutan BPHTB mencakup seluruh rangkaian proses yang harus dilakukan dalam menerima, menatausahakan, dan

\footnotetext{
${ }^{3}$ Amin Purnawan, Rekonstruksi Politik Hukum Pajak Penghasilan (PPh) Badan Berbasis Nilai Keadilan (Studi Tentang Keadilan Beban Pajak), Ringkasan Disertasi, Program Doktor Ilmu Hukum, Universitas Diponegoro, Semarang, 2011, hlm. 3 dan 4.

4 Mustofa Kamal, Wawancara, selaku Kasubid Pemeriksaan Badan Keuangan Daerah Kota Pekalongan, pada tanggal 9 Agustus 2017.
}

melaporkan penerimaan BPHTB. Prosedur pemungutan BPHTB di Kota Pekalongan berdasarkan Peraturan Walikota Pekalongan Nomor 35 Tahun 2010, meliputi prosedur pengurusan akta pemindahan hak atas tanah dan/atau bangunan, prosedur pembayaran BPHTB, prosedur penelitian Surat Setoran Pajak Daerah BPHTB, prosedur pendaftaran akta pemindahan hak atas tanah dan/atau bangunan, prosedur pelaporan BPHTB, prosedur penagihan, dan prosedur pengurangan. ${ }^{5}$

Untuk melaksanakan sistem dan prosedur pemungutan BPHTB, maka Satuan Kerja Pengelola Keuangan Daerah harus mempersiapkan fungsi yang dibutuhkan, meliputi fungsi pelayanan, fungsi data dan informasi, serta fungsi pembukuan dan pelaporan. ${ }^{6}$

Sistem dan prosedur pemungutan BPHTB di Kota Pekalongan sebagaimana diatur di dalam Peraturan Walikota Pekalongan Nomor 35 Tahun 2010 meliputi pengurusan akta pemindahan hak atas tanah dan/ atau bangunan, pembayaran BPHTB, penelitian SSPD BPHTB, pen-daftaran akta pemindahan hak, pelaporan BPHTB, penagihan BPHTB, dan pengurangan BPHTB. $^{7}$

Kepala SKPKD melakukan fasilitasi dalam melaksanakan Per-aturan Walikota Pekalongan Nomor 35 Tahun 2010. Fasilitasi tersebut, mencakup mengkoordinasikan, menyempurnakan lampiran-lampiran sesuai dengan ketentuan perundang-undangan, melaksanakan, sosialisasi, supervisi dan bimbingan teknis, serta memberikan asistensi untuk kelancaran penerapan Peraturan Walikota Pekalongan Nomor 35 Tahun 2010. ${ }^{8}$

2. Kendala yang dihadapi di dalam pelaksanaan Perwal Pekalongan Nomor 35 Tahun 2010 di Kota Pekalongan;

Keberadaan pajak adalah sebagai sumber keuangan terhadap kepentingan umum, cara memperolehnya dengan paksa dan sebagai kewajiban, maksudnya perolehannya itu sesuai dengan kesepakatan, pajak ibarat senjata bermata dua, ada yang berdasarkan pada pemerintah dan ada yang menggunakan pendekatan kepemimpinan dalam

\footnotetext{
${ }^{5}$ Ibid.

${ }^{6}$ Ibid.

7 Ibid.

${ }^{8}$ Ibid.
} 
memikul beban untuk menutupi kebutuhan pangan masyarakat. Pajak suatu saat akan menjadi beban berat bagi pemilik harta yang mengharuskan pemerintah melihat situasi dan kondisi keuangan.

Berpegang pada kaidah-kaidah dasar bahwa dalam menetapkan pajak itu adalah menghindari kekuasaan, maka terjadi kesepakatan antara kesejah-teraan harta dan kesejahteraan pemilik harta, khususnya setelah terjadi perkembangan tujuan pajak untuk mencapai tujuan sosial, ekonomi dan politik. Ada pemikiran keuangan dari kaidahkaidah ini, di mana munculnya kaidah-kaidah itu ditujukan kepada filosof abad 18 dan 19, seperti ekonom Inggris Adam Smith yang memuat kaidah ini dalam bab kedua dari bukunya "Kekayaan Masyarakat" tahun 1776, ekonom Fajnar dan Sismundie. $^{9}$

Hukum pajak perlu memberikan arahan perpajakan pada masya-rakat untuk membentuk jiwa yang loyal kepada negara, ini dilakukan dengan cara yang arif, berakhlak dan melindungi untuk membantu masyarakat dalam mewujudkan tujuantujuan politik keuangan dengan cara yang baik dengan memberdayakan sumber keuangan, yaitu pajak.

Terkait dengan pemungutan BPHTB di Kota Pekalongan, masya-rakat Kota Pekalongan tidak berkeberatan dalam BPHTB, selama jumlah pajak yang harus dibayarkan tersebut tidak memberatkan wajib pajak. $^{10}$

Kendala yang dihadapi dalam pemungutan BPHTB di Kota Pekalongan adalah ketidakjujuran dari wajib pajak tentang harga riil nilai perolehan objek pajak. Dinas Pendapatan Pengelolaan Keuangan dan Aset Daerah Kota Pekalongan sudah menentukan besarnya pajak yang harus dibayar oleh wajib pajak, akan tetapi wajib pajak tidak mau membayar sesuai dengan jumlah yang telah ditentukan dan meminta pengurangan BPHTB. ${ }^{11}$

Pengurangan BPHTB di Kota Pekalongan, banyak dilakukan proses waris dan hibah. Untuk jualbeli karena wajib pajak banyak yang tidak memberikan harga riil, maka permintaan pengurang-

\footnotetext{
${ }^{9}$ Gazi Inayah, Teori Komprehensip Tentang Zakat dan Pajak, Cetakan Kesatu, Tiara Wacana Yogya, Yogyakarta, 2003, hlm. 43.

${ }_{10}$ Mustofa Kamal, Op.Cit

${ }^{11}$ Ibid.
}

an BPHTB tidak dapat disetujui. Untuk hibah dan waris pengurangan BPHTB dapat di-setujui, yang disesuaikan dengan Nilai Jual Objek Pajak (NJOP). ${ }^{12}$

3. Upaya di dalam mengatasi kendala-kendala di dalam pelaksanaan Perwal Pekalongan Nomor 35 Tahun 2010.

Upaya yang dilakukan oleh Dinas Pendapatan Pengelolaan Keuangan dan Aset Daerah Kota Pekalongan terhadap wajib pajak yang tidak jujur dalam memberikan harga riil nilai jual objek pajak untuk Bea Perolehan Hak Atas Tanah dan Bangunan, terutama dalam jual-beli, maka dilakukan cek lokasi terhadap objek yang dikenai Bea Perolehan Hak Atas Tanah dan Bangunan. ${ }^{13}$

Kebijakan lain yang dikeluarkan oleh Dinas Pendapatan Penge-lolaan Keuangan dan Aset Daerah Kota Pekalongan adalah jika wajib pajak tersebut adalah warga tidak mampu, diberikan pengurangan terhadap Bea Perolehan Hak Atas Tanah dan Bangunan, dan disesuaikan dengan kondisi wajib pajak, sehingga tidak membebani dan memberatkan wajib pajak bersangkutan. ${ }^{14}$

Perlu kesadaran yang tinggi agar wajib pajak mau membayar pajak, oleh karena manfaat pajak akan kembali pada masyarakat, yakni untuk kesejahteraan masyarakat, bukan untuk kepentingan orang tertentu.

\section{PENUTUP}

1. Pelaksanaan Perwal Pekalongan Nomor 35 Tahun 2010 mencakup seluruh rangkaian proses yang harus dilakukan dalam menerima, menatausahakan, dan melaporkan penerimaan BPHTB, yang meliputi pengurusan akta pemindahan hak atas tanah dan/atau bangunan, pembayaran BPHTB, penelitian Surat Setoran Pajak Daerah BPHTB, pendaftaran akta pemindahan hak atas tanah dan/atau bangunan, pelaporan BPHTB, penagihan, dan pengurangan;

2. Kendala yang dihadapi di dalam pelaksanaan Perwal Pekalongan Nomor 35 Tahun 2010 adalah ketidakjujuran dari wajib pajak tentang harga riil nilai perolehan objek pajak. Dinas Pendapatan

\footnotetext{
${ }^{12}$ Ibid.

13 Ibid.

${ }^{14}$ Ibid.
} 


\section{JURNAL AKTA}

Pengelolaan Keuangan dan Aset Daerah Kota Pekalongan sudah menentukan besarnya pajak yang harus dibayar oleh wajib pajak, akan tetapi wajib pajak tidak mau membayar sesuai dengan jumlah yang telah ditentukan dan meminta pengurangan Bea Perolehan Hak Atas Tanah dan Bangunan;

3. Upaya di dalam mengatasi kendala-kendala di dalam pelaksanaan Perwal Nomor 35 Tahun 2010 maka dilakukan cek lokasi terhadap objek yang dikenai BPHTB. Kebijakan lain yang dikeluarkan oleh Dinas Pendapatan Pengelolaan Keuangan dan Aset Daerah Kota Pekalongan adalah jika wajib pajak tersebut adalah warga tidak mampu, diberikan pengurangan terhadap BPHTB, dan disesuaikan dengan kondisi wajib pajak, sehingga tidak membebani dan memberatkan wajib pajak bersangkutan.

\section{Daftar Pustaka}

Buku-buku :

Gazi Inayah, Teori Komprehensip Tentang Zakat dan Pajak, Cetakan Kesatu, Tiara Wacana Yogya, Yogyakarta, 2003.

Gusfahmi, Pajak Menurut Syariah, Edisi Revisi, Cetakan Kedua, Rajawali Pers, Jakarta, 2011.

M. Ali Hasan, Masail Fiqhiyah, Zakat, Pajak, Asuransi dan Lembaga Keuangan, Edisi Pertama, Cetakan Kedua, Raja Grafindo Persada, Jakarta, 1997.

Makalah/Jurnal Hukum/Karya Ilmiah :

Amin Purnawan, Rekonstruksi Politik Hukum Pajak Penghasilan (PPh) Badan Berbasis Nilai Keadilan (Studi Tentang Keadilan Beban Pajak), Ringkasan Disertasi, Program Doktor Ilmu Hukum, Universitas Diponegoro, Semarang, 2011. 